\title{
Role of Cytokines in Allergic Airway Inflammation
}

\author{
Hiroshi Nakajima ${ }^{a}$ Kiyoshi Takatsu ${ }^{b}$ \\ a Department of Molecular Genetics, Graduate School of Medicine, Chiba University, Chiba, and \\ ${ }^{b}$ Division of Immunology, Department of Microbiology and Immunology, Institute of Medical Science, \\ University of Tokyo, Tokyo, Japan
}

\section{Key Words}

Cytokines · Th1 cells · Th2 cells · Airway inflammation

\begin{abstract}
Asthma is characterized by intense infiltration of eosinophils and CD4+ T cells into the submucosal tissue of airways. Accumulating evidence indicates that $T$ helper type 2 cell-derived cytokines such as interleukin (IL)-4, IL-5 and IL-13 play critical roles in orchestrating and amplifying allergic inflammation in asthma. In addition, it has been suggested that newly identified cytokines including thymic stromal lymphopoietin, IL-25 and IL-33 are involved in the induction of allergic inflammation in asthma. In this review, we discuss the role of individual cytokines in the pathogenesis of asthma.

Copyright $\odot 2007$ S. Karger AG, Basel
\end{abstract}

\section{Introduction}

Immediate hypersensitivity allergic reactions are dependent on degranulation of activated mast cells and peak within $30 \mathrm{~min}$. Over the subsequent several hours, the late-phase allergic reaction (LAR) evolves, peaks at 6-12 $\mathrm{h}$ and may persist for several days. In contrast to the immediate hypersensitivity reaction in which histologic findings are predominantly edema and vasodilatation, the LAR is characterized by a prominent leukocytic infiltrate comprised of eosinophils, T helper (Th) 2 cells and neutrophils [1-3].

\section{KARGER \\ Fax +41613061234 E-Mail karger@karger.ch} www.karger.com

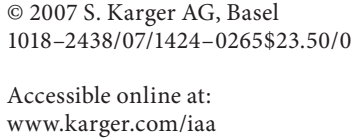

Asthma is a common respiratory disorder characterized by recurrent episodes of coughing, breathlessness and wheezing. It is well established that a strong correlation exists between the presence of eosinophils and the presence of Th2 cells in the asthmatic airways and that classical Th2 cell-derived cytokines, namely interleukin (IL)-4, IL-5, IL-9 and IL-13, play critical roles in orchestrating and amplifying allergic inflammation in asthma. However, accumulating evidence suggests that the regulation of allergic inflammation is more complex. This review will explore our current understanding of the role of individual cytokines in the pathogenesis of asthma with a particular focus on nonclassical cytokines in the mechanism underlying allergic airway inflammation.

\section{Role of Classical Th2 Cytokines in Causing Allergic Inflammation}

\section{Interleukin-4}

Allergic diseases including asthma are characterized by inflammation with pronounced infiltration of eosinophils [1-3]. An essential biological activity of IL-4 in the development of allergic inflammation is to drive the differentiation of naive Th0 cells into Th2 cells, which secrete IL-4, IL-5, IL-9 and IL-13 but not interferon (IFN)- $\gamma[4,5]$. Studies using IL-4-deficient mice clearly showed that IL-4 was required for the development of allergic inflammation, as antigen-induced allergic inflammation was significantly decreased in IL-4-deficient mice as compared with wild-type mice [6]. Coyle et al. [7] also

Correspondence to: Dr. Hiroshi Nakajima

Department of Molecular Genetics, Graduate School of Medicine

Chiba University 1-8-1 Inohana

Chiba City, Chiba 260-8670 (Japan)

Tel. +81 43226 2197, Fax +81 43226 2199, E-Mail nakajimh@faculty.chiba-u.jp 
demonstrated that the administration of neutralizing anti-IL-4 antibody prior to antigen immunization prevented the development of antigen-induced airway inflammation, whereas the administration of the same antibody after immunization but prior to antigen inhalation was not effective for preventing antigen-induced airway inflammation. These studies suggest that while IL-4 is essential for the initial differentiation and/or expansion of antigen-specific Th2 cells, IL- 4 may not be essential for the induction of allergic airway inflammation at an effector phase. On the other hand, some studies have indicated the importance of IL-4 in promoting allergic inflammation at an effector phase by inducing the recruitment of Th2 cells in part via vascular cell adhesion molecule-1/very late antigen-4-dependent mechanisms $[8,9]$. In addition, a clinical trial of soluble IL-4 receptor (IL-4R) that neutralizes IL-4 function showed the therapeutic benefit in moderately severe asthma [10]. Therefore, IL-4 could play a role in the induction of allergic inflammation in a sensitized individual, but the relative importance of IL- 4 depends on the state of sensitization and/or genetic background.

\section{Interleukin-5}

IL-5 has been originally defined as a T cell-derived cytokine that triggers activated $\mathrm{B}$ cells for a terminal differentiation into immunoglobulin-producing cells [11]. Concurrently, IL-5 has been recognized as the major maturation and differentiation factor for eosinophils [12, 13]. It has been demonstrated that the expression of IL-5 mRNA in bronchial biopsies of asthmatic patients is increased as compared with healthy volunteers and that the predominant source of IL-5 mRNA is CD4+ T cells [14]. Indeed, $\mathrm{CD} 4+\mathrm{T}$ cell activation in asthma is accompanied by increased serum concentrations of IL-5 [15]. IL-5 mRNA and protein are also found in mast cells located within allergen-challenged tissues. Based on these observations, an attractive paradigm for eosinophil involvement in the LAR is (1) the upregulation of IL-5 synthesis by mast cells activated in an immediate hypersensitivity allergic reaction, resulting in (2) eosinophil recruitment and activation [1-3]. Concomitantly, (3) CD4+ T cells are recruited by other inflammatory mediators of the allergic reaction and undergo antigen-specific activation and acquisition of the Th2 phenotype which (4) further enhances eosinophil recruitment and activation.

Animal models further support a role for IL-5 in the induction of eosinophilic inflammation in allergies and asthma. It has been shown that the enforced expression of IL- 5 by transgene causes eosinophilia [16-18]. A piv- otal role for IL-5 in the late asthmatic response has been confirmed by the capacity for neutralizing anti-IL-5 monoclonal antibody (mAb) to inhibit antigen-induced airway hyperresponsiveness and eosinophil infiltration in the airways of mice and guinea pigs [19-21]. Importantly, administration of neutralizing anti-IL-5 mAb reduced airway eosinophilia when administered within hours preceding respiratory antigen challenge or when administered up to 5 days after antigen challenge. The lack of bronchial hyperreactivity and eosinophilia in the lungs of antigen-sensitized and antigen-challenged IL-5deficient and IL-5R $\alpha$ chain (IL-5R $\alpha$ )-deficient mice further demonstrated the importance of IL-5 in allergic airway inflammation [22-25].

Results of humanized anti-IL-5 mAb treatment in patients with mild asthma confirmed the importance of IL-5 in eosinophilic inflammation in human [26]. However, anti-IL-5 antibody did not reduce asthmatic symptoms and airway reactivity [26], suggesting that airway hyperresponsiveness occurs independently of IL-5 and airway eosinophilia. Recently, the role of IL-5 and eosinophils in the development of airway remodeling, in an experimental model of chronic asthma, has been carefully studied by using mice lacking IL-5R $\alpha$ or mice transgenic for IL-5 [27]. The study has demonstrated that IL-5 plays an obligatory role in the airway remodeling observed in experimental asthma [27]. Intriguingly, treatment of wild-type mice with anti-IL-5 antibody almost completely prevented subepithelial and peribronchial fibrosis caused by antigen inhalation [27]. Importantly, anti-IL-5 antibody treatment has also been shown to improve airway remodeling in asthmatic patients $[28,29]$. Further studies are required to define the mechanism underlying IL-5 and eosinophil-mediated airway remodeling in asthma. It may be worthwhile to test the feasibility of humanized anti-IL-5R $\alpha$ antibody in a monkey asthma model for eliminating eosinophils localized in the airways by antibody-dependent cell-mediated cytotoxicity.

\section{Interleukin-13}

Accumulating evidence suggests that IL-13 plays a key role in the allergic response via its actions on epithelial and smooth muscle cells and not through traditional effector pathways involving eosinophils and immunoglobulin E (IgE)-mediated events [30-32]. The importance of IL-13 was evidenced by the finding that neutralization of endogenously released IL-13 with a soluble form of IL$13 \mathrm{R} \alpha 2$, which binds IL-13 but not IL-4, during antigen exposure largely inhibited the characteristics of asthma in murine asthma models $[33,34]$. In addition, antigen 
challenge of IL-13-deficient mice failed to elicit airway hyperresponsiveness and mucus production despite the continued presence of IL- 4 and IL-5 and airway inflammation [35]. Its importance as an effector molecule in asthma was further evidenced by the finding that acute administration of IL-13 itself was sufficient to recapitulate many features of airway responses characterized in asthma, such as eosinophilic inflammation, mucus hyperproduction and airway hyperresponsiveness in mice $[33,34]$. Moreover, lung-specific expression of IL-13 resulted in the development of characteristic features of asthma [36]. These results suggest that IL-13, independent from other Th2 cytokines, is necessary and sufficient to induce key features of allergic inflammation at an effector phase. Importance of IL-13 in asthma was also supported by strong associations between genetic polymorphisms in the IL-13 gene and asthma [37]. The role of IL-13 in the pathogenesis of asthma has been described in more detail in recent reviews [30-32].

\section{Interleukin-9}

Another Th2 cell-derived cytokine that seems involved in the pathogenesis of asthma is IL-9 [38]. First, genetic analyses revealed the possible involvement of IL-9 in causing airway hyperresponsiveness [39]. In addition, it has been demonstrated that the expression of IL-9 is increased in bronchial biopsy samples of asthmatics [40]. Lung-specific overexpression of IL-9 by transgene has also been shown to induce airway hyperresponsiveness in addition to morphological changes that bear similarities to asthma [41]. Neutralizing antibodies against IL-9 further demonstrate a crucial role for IL-9 in the development of the allergic asthmatic response [42]. On the other hand, although IL-9 plays a role in goblet cell hyperplasia and mast cell development, experiments analyzing IL-9-deficient mice show that it has little or no effect on eosinophils, T cell development or immunoglobulin response [43]. Further study is required for clarifying the role of IL-9 in the regulation of allergic airway inflammation.

\section{Role of Th1 Cytokines in the Regulation of Allergic Airway Inflammation}

\section{Interferon- $\gamma$}

IFN- $\gamma$, the principal Th1 effector cytokine, has been shown to be crucial for the resolution of allergic inflammation. Using murine asthma models, IFN- $\gamma$ has been shown to prevent the development of antigen-induced airway eosinophilia and hyperresponsiveness [44, 45]. It has also been shown that IFN- $\gamma$ receptor (IFN- $\gamma$ R)-deficient mice exhibit a prolonged airway eosinophilia in response to allergen inhalation [46]. In accordance with these findings, we found that mice lacking T-bet, the master regulator of Th1 cell development and IFN- $\gamma$ production [5], exhibited enhanced antigen-induced allergic airway inflammation [Fujiwara et al., submitted]. These results suggest that IFN- $\gamma$ could counterbalance Th 2 cellmediated allergic airway inflammation. On the other hand, some studies have shown that the coexistence of Th1 cells aggravates the Th2 cell-mediated allergic responses [47-49]. Using cell transfer experiments, it has been shown that allergen-specific Th1 cells enhance Th2 cell-mediated asthmatic airway responses [47-49], presumably by inducing the production of tumor necrosis factor (TNF)- $\alpha$ and subsequent vascular cell adhesion molecule-1 expression at the inflamed site [49]. Because IFN- $\gamma$ itself potently inhibits Th2 cell activation $[4,5]$ and allergic airway inflammation [44, 45], it is suggested that the balance between IFN- $\gamma$ and TNF- $\alpha$ produced by activated Th1 cells may be a key determinant of the role of Th1 cells in the regulation of allergic airway inflammation.

\section{Interleukin-12}

IL-12 is produced by antigen-presenting cells such as dendritic cells (DCs) and macrophages and is known to play an important role in Th1 differentiation during primary antigen presentation [50]. In asthmatic individuals, it has been shown that IL-12 expression is reduced in bronchial biopsy samples [51]. In addition, murine asthma models have confirmed that exogenous administration of IL-12 during the primary sensitization suppresses allergen-induced Th2 development and subsequent allergic inflammation [52]. Interestingly, even when IL-12 is administered only during antigen challenge, IL-12 retains the capacity to inhibit allergen-induced allergic inflammation and airway hyperresponsiveness $[52,53]$. Because fully differentiated Th2 cells have been shown to lose IL-12 responsiveness [54], a reversal of Th2 cells towards a Th1 phenotype at this stage seems unlikely. IL-12 may suppress Th2 cell-mediated allergic inflammation by augmenting the production of IFN- $\gamma$ from coexisting Th1 cells, CD8+ T cells or natural killer cells.

\section{Interleukin-18}

IL-18 was initially described as IFN- $\gamma$-releasing factor [55]. Consistent with this finding, the absence of endogenous IL-18 in IL-18-deficient mice resulted in enhanced 
antigen-induced airway eosinophilia [56]. In addition, IL-12 and IL-18 act synergistically in inducing IFN- $\gamma$ production and inhibit IL-4-dependent IgE synthesis and allergen-induced airway hyperresponsiveness [57]. These results suggest that IL-18 functions as a negative regulator for allergic inflammation. On the other hand, it has recently been shown that Thl cells come to produce a large amount of Th 2 cytokines such as IL- 9 and IL-13 and robust IFN- $\gamma$ and TNF- $\alpha$ when stimulated with antigen plus IL-18, while Th1 cells do not produce IL-9 and IL-13 and produce less amounts of IFN- $\gamma$ and TNF- $\alpha$ when stimulated with antigen in the absence of IL-18 [58]. Moreover, when Th1 cell-transferred mice are challenged with antigen and IL-18, mice develop severe airway inflammation characterized by massive infiltration of eosinophils as in the antigen-challenged Th2 cell-transferred mice [58]. Furthermore, we have demonstrated that the administration of IL-18 enhances antigen-induced eosinophil recruitment into the airways of sensitized mice in part by increasing antigen-induced TNF- $\alpha$ production [59]. Thus, it is suggested that the function of IL-18 depends on the environmental cytokines [60]. Further study is needed to address the molecular basis for the pleiotrophic function of IL-18.

\section{Interleukin-27}

IL-27, an IL-12-related cytokine with pro- and anti-inflammatory properties, is composed of $\mathrm{p} 28$ subunit and EBI3 [61]. The cells responsible for IL-27 production are DCs and macrophages [61]. IL-27R is composed of gp130 and WSX1, which was known as an orphan receptor that induces Th1 cell differentiation [61]. An early study has indicated that IL-27 functions as a proinflammatory cytokine because it synergizes with IL-12 to promote Th1 responses [61]. Th1 deviation by IL-27 is due in part to the induction of T-bet [62]. A recent study has also shown that addition of IL-27 to naive T cells under Th2-polarizing conditions decreases the expression of GATA-3, a master regulator for Th2 development, and thus IL-4 production [63]. Consistent with these findings, ovalbumin-challenged WSX1-deficient mice showed a marked enhancement of Th2 cytokine production, eosinophil infiltration into the airway, and airway hyperresponsiveness with goblet cell hyperplasia [64], suggesting that IL27 functions as a negative regulator of Th2-type immune responses in vivo. Interestingly, IFN- $\gamma$ production was also enhanced in WSX1-deficient mice [64]. Therefore, these results suggest that the enhanced allergic responses in WSX1-deficient mice seem to be independent from the Th1-promoting property of IL-27.

\section{Proinflammatory Cytokines in the Allergic Inflammation}

\section{IL-17 Family Cytokines}

The original member of the IL-17 family, IL-17A, was identified in 1995, and subsequently, 5 cytokines, IL-17B, IL-17C, IL-17D, IL-17E (also known as IL-25) and IL-17F, were identified as IL-17 family cytokines [65]. IL-17A and IL-17F are mainly expressed in a recently identified subpopulation of CD $4+\mathrm{T}$ cells, namely $\mathrm{Th} 17$ cells, which are believed to be involved in the pathogenesis of autoimmune diseases [66]. Both IL-17A and IL-17F induce the expression of a variety of cytokines and chemokines including IL-6, granulocyte macrophage colony-stimulating factor and CXCL10 from epithelial and vascular endothelial cells and induce IL- 8 from fibroblasts $[65,67$, 68]. The ability of IL-17A and IL-17F to evoke migration of neutrophils but not of eosinophils makes it likely that these cytokines are involved in severe asthma, in which accumulation of neutrophils in the airways is a hallmark of disease [69]. Because IL-17 and IL-17F are expressed in the airway of asthmatic patients [67], these cytokines may constitute a link between the activation of T cells and recruitment of neutrophils into the airways.

IL-25 is produced by activated Th2 cells [70] and mast cells [71]. The in vivo and in vitro biological activities of IL-25 are markedly different from those described for IL17 and other IL-17 family cytokines $[65,70,72,73]$. Systemic administration of IL-25 protein [70] or the systemic expression of IL-25 by transgene [73] induces the production of IL-4, IL-5 and IL-13 from undefined non-T/non-B cells and the resultant Th2-type immune responses including blood eosinophilia, increased serum IgE levels and pathological changes in the lung and other tissues. We also found that IL-25 mRNA was expressed in the lung upon antigen inhalation and that neutralization of endogenously produced IL-25 by soluble IL-25R decreased antigen-induced eosinophil and CD4+ T cell recruitment into the airways [74]. In addition, we found that although the enforced expression of IL-25 in the lung itself failed to induce allergic airway inflammation, the expression of IL-25 significantly enhanced antigen-induced eosinophil and Th2 cell recruitment in the airways [74]. Moreover, IL-25-induced enhancement of antigeninduced eosinophil recruitment into the airways was inhibited by the depletion of CD4+ T cells [74]. These findings indicate that IL-25 plays an important role in enhancing antigen-induced allergic airway inflammation by amplifying a Th2 cell-dependent pathway. Furthermore, the enhanced expression of IL-25 in the airway of 
asthmatic patients has been recently reported [75]. These findings raise the possibility that IL-25 may be involved in the enhancement and/or prolongation of Th2 cell-mediated allergic inflammation in asthma and suggest that IL- 25 could be a possible target of allergic diseases.

\section{Tumor Necrosis Factor- $\alpha$}

The proinflammatory activities of TNF- $\alpha$ including leukocyte recruitment through the upregulation of adhesion molecules on endothelial cells and induction of cytokine and chemokine synthesis seem involved in the pathogenesis of asthma [76]. Elevated levels of TNF- $\alpha$ have been detected in bronchoalveolar lavage fluid and biopsy samples in asthmatic patients [77]. Inhalation of TNF- $\alpha$ also causes airway hyperresponsiveness and an increase in sputum neutrophil counts in healthy volunteers [78]. On the other hand, it has been shown that pretreatment with anti-TNF- $\alpha$ antibodies profoundly reduces the endotoxin or IL-18-induced airway changes in a rodent model [59, 79]. More recently, treatment with TNF- $\alpha$ antagonist etanercept has been shown to reduce airway hyperreactivity and asthma symptoms [80], suggesting the in vivo relevance of TNF- $\alpha$ in the pathogenesis of severe asthma.

\section{Roles of Other Cytokines (Thymic Stromal Lymphopoietin, IL-21, IL-31 and IL-33) in Allergic Inflammation}

\section{Thymic Stromal Lymphopoietin}

Thymic stromal lymphopoietin (TSLP) is an IL-7-like cytokine that may trigger Th2-type inflammation [81]. TSLP is highly expressed in skin keratinocytes and airway epithelial cells during allergic inflammation [81]. Functional TSLP receptor (TSLPR) consists of TSLPR and IL-7R $\alpha$ chain $[82,83]$. TSLP induces the maturation of DCs, especially the induction of OX40L, without driving the production of the Th1-polarizing cytokine such as IL-12 [84]. Consequently, TSLP-stimulated DCs trigger Th2 polarization, promote TNF- $\alpha$ production and inhibit IL-10 production [84]. The resultant Th2 cells that produce high levels of TNF- $\alpha$ but little IL-10 may be more potent in inducing allergic inflammation than conventional Th2 cells. In addition, TSLP-stimulated DCs have recently been shown to induce a robust expansion and further polarization of Th2 memory cells [85]. Moreover, TSLP-stimulated DCs produce a number of chemokines which may participate in the recruitment of neutrophils, eosinophils and Th2 cells into the site of allergic inflam- mation [81]. Indeed, lung-specific expression of TSLP by transgene results in airway inflammation and hyperreactivity [86]. Furthermore, it has been demonstrated that TSLP expression is increased in the lungs of sensitized mice upon antigen inhalation [86] and that TSLPR-deficient mice exhibit attenuated responses to the inhaled antigen $[86,87]$. A recent study has also shown that TSLP expression is increased in asthmatic airway in humans and is correlated with the expression of Th2 cell-attracting chemokines and disease severity [88]. These findings suggest that TSLP is involved in the induction of airway inflammation in asthma and that TSLP is a possible target for immunological intervention in the treatment of allergic diseases.

\section{Interleukin-21}

IL-21 is a product of activated CD4+ T cells, and IL$21 \mathrm{R}$ consists of IL-21R $\alpha$ and common cytokine receptor $\gamma$ chain [89]. Recent studies indicate that IL-21 is involved in the downregulation of IgE production [90-92]. Naive IL-21R $\alpha$-deficient mice showed a considerably higher serum concentration of IgE than wild-type mice $[90,91]$. Interestingly, immunization of IL-21R $\alpha$-deficient mice with ovalbumin or keyhole limpet hemocyanin results in higher levels of IgE compared with wild-type mice, without affecting IL-4 production [91]. In accordance with these findings, administration of recombinant IL-21 decreases antigen-specific IgE production and attenuates antigen-induced eosinophil recruitment into the airways in sensitized mice [92]. These effects of IL-21 on IgE production and eosinophil recruitment into the airways in an asthma model indicate that IL-21 might have an important regulatory role in airway responses to antigens and suggest that increasing the levels of IL-21 might be of value for treating allergic diseases, such as asthma. On the other hand, it has recently been demonstrated that IL-21 inhibits IFN- $\gamma$ production in developing Th1 cells by repressing the expression of a T-bet-related transcription factor eomesodermin [93], suggesting that IL-21 may have diverse roles in the regulation of allergic airway inflammation.

\section{Interleukin-31}

IL-31 seems most closely related to oncostatin M, leukemia inhibitory factor and cardiotrophin-1 and is expressed in activated CD4+ T cells, with the highest levels found in T cells activated in Th2-polarizing conditions [94]. IL-31 induces the expression of a large number of chemokines without altering cytokine levels [94], suggesting that IL-31 is involved in the recruitment of inflamma- 
Fig. 1. Cytokine-mediated crosstalk in the regulation of allergic inflammation. Representative cytokine-mediated pathways for the induction and suppression of allergic inflammation are shown. APCs = Antigen-presenting cells; VCAM-1 = vascular endothelial growth factor 1.

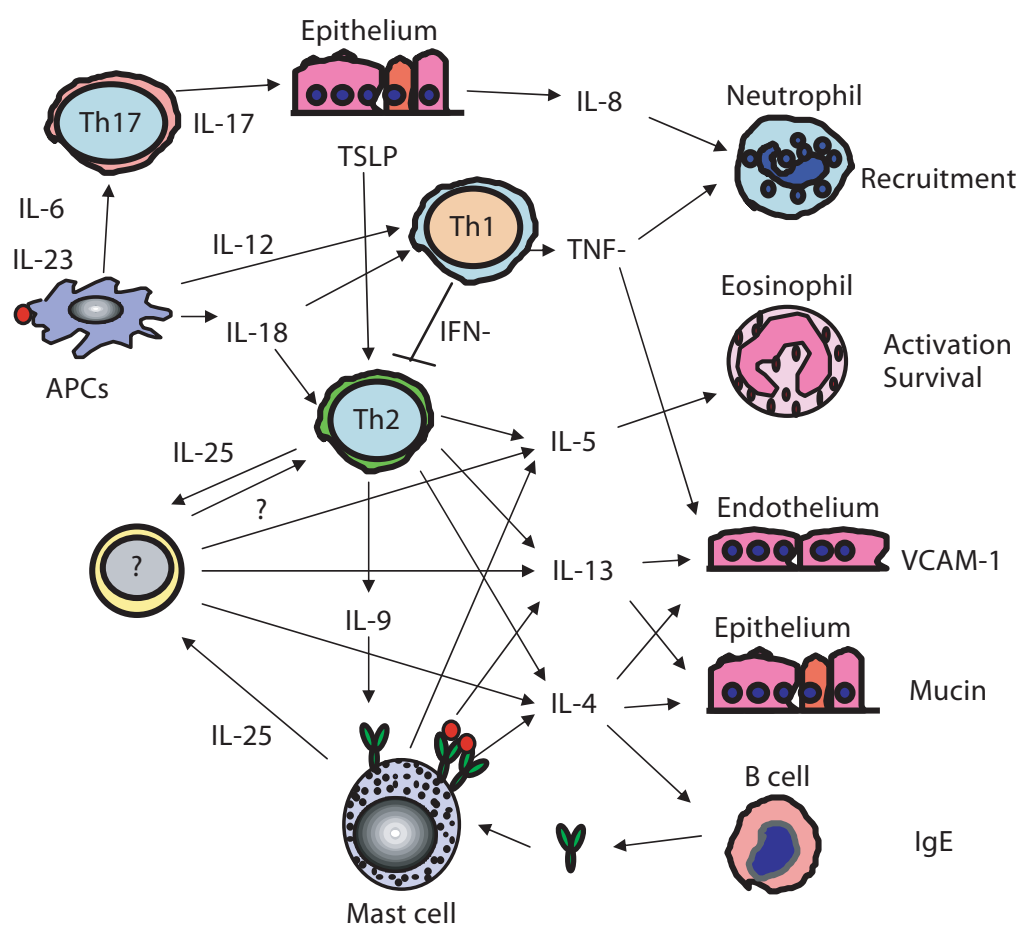

tory cells to the sites. Indeed, mice expressing IL-31 in skin showed an increase in the number of lesions with an inflammatory cell infiltrate similar to that observed in atopic dermatitis [94]. In addition, it has been demonstrated that activated leukocytes in patients with atopic dermatitis expressed significantly higher IL-31 levels as compared with control subjects $[95,96]$. The possible involvement of IL-31 in allergic airway inflammation warrants further investigation in light of these early findings.

\section{Interleukin-33}

ST2 is an IL-1R-related protein expressed on Th2 cells and mast cells [97]. ST2 has been shown to function as an important effector molecule of Th2 responses in a number of experimental settings including mouse asthma models [98-100]. Recently, an IL-1-like cytokine, IL-33, has been identified as a ligand for ST2 [101]. It has been demonstrated that IL-33 is produced by many cell types including smooth muscle cells, epithelial cells and DCs and drives production of IL- 5 and IL-13 from in vitro polarized Th2 cells [101]. These findings suggest that IL-33/ ST2 interaction may play a significant role in the induction of allergic airway inflammation.

\section{Conclusion}

There is overwhelming evidence to support a major role for T cells, especially Th2 cells, and their cytokines in asthma (fig. 1). In addition to classical Th2 cytokines such as IL-4, IL-5, IL-9 and IL-13, other cytokines derived from Th2 cells, including IL-25 and IL-31, have also been shown to play an important role in causing allergic inflammation. Non-lymphoid cell-derived cytokines such as IL-33 and TSLP are also involved in the induction of allergic inflammation through the induction of Th2 cell differentiation. Further studies identifying relative importance of these cytokines in asthmatic patients are needed to uncover therapeutic targets for asthma. 


\section{References}

$\checkmark 1$ Kay AB: Allergy and allergic diseases. First of two parts. N Eng J Med 2001;344:30-37.

-2 Cohn L, Elias JA, Chupp GL: Asthma: mechanisms of disease persistence and progression. Annu Rev Immunol 2004;22:789-815.

3 Takatsu K, Dickason R, Huston D: Interleukin-5; in Le Roith D (ed): Growth Factors and Cytokines in Health and Disease. New York, Academic Press, 1997, vol IIA, pp 143200.

4 O'Garra A, Arai N: The molecular basis of T helper 1 and $\mathrm{T}$ helper 2 cell differentiation. Trends Cell Biol 2000;10:542-550.

$\checkmark 5$ Murphy KM, Reiner SL: The lineage decisions of helper $\mathrm{T}$ cells. Nat Rev Immunol 2002;2:933-944.

-6 Brusselle GG, Kips JC, Tavernier JH, van der Heyden JG, Cuvelier CA, Pauwels RA, Bluethmann $\mathrm{H}$ : Attenuation of allergic airway inflammation in IL-4 deficient mice. Clin Exp Allergy 1994;24:73-80.

-7 Coyle AJ, Le Gros G, Bertrand C, Tsuyuki S, Heusser CH, Kopf M, Anderson GP: Interleukin-4 is required for the induction of lung Th2 mucosal immunity. Am J Respir Cell Mol Biol 1995;13:54-59.

$\checkmark 8$ Nakajima H, Sano H, Nishimura T, Yoshida S, Iwamoto I: Role of vascular cell adhesion molecule 1 /very late activation antigen 4 and intercellular adhesion molecule 1/lymphocyte function-associated antigen 1 interactions in antigen-induced eosinophil and $\mathrm{T}$ cell recruitment into the tissue. J Exp Med 1994;179:1145-1154.

-9 Cohn L, Homer RJ, Marinov A, Rankin J, Bottomly K: Induction of airway mucus production by T helper 2 (Th2) cells: a critical role for interleukin 4 in cell recruitment but not mucus production. J Exp Med 1997;186: 1737-1747.

-10 Borish LC, Nelson HS, Lanz MJ, Claussen L, Whitmore JB, Agosti JM, Garrison L: Interleukin-4 receptor in moderate atopic asthma. A phase I/II randomized, placebo-controlled trial. Am J Respir Crit Care Med 1999;160:1816-1823.

-11 Takatsu K, Takaki S, Hitoshi Y: Interleukin-5 and its receptor system: implications in the immune system and inflammation. Adv Immunol 1994;57:145-190.

-12 Koike M, Takatsu K: IL-5 and its receptor: which role do they play in the immune response? Int Arch Allergy Immunol 1994; 104:1-9.

$\checkmark 13$ Rothenberg ME, Hogan SP: The eosinophil. Annu Rev Immunol 2006;24:147-174.

-14 Robinson DS, Hamid Q, Ying S, Tsicopoulos A, Barkans J, Bentley AM, Corrigan C, Durham SR, Kay AB: Predominant Th2-like bronchoalveolar T-lymphocyte population in atopic asthma. N Engl J Med 1992;326: 298-304.
15 Corrigan CJ, Haczku A, Gemou-Engesaeth V, Doi S, Kikuchi Y, Takatsu K, Durham SR, Kay AB: CD4 T-lymphocyte activation in asthma is accompanied by increased serum concentrations of interleukin-5. Effect of glucocorticoid therapy. Am Rev Respir Dis 1993;147:540-547.

16 Dent LA, Strath M, Mellor AL, Sanderson CJ: Eosinophilia in transgenic mice expressing interleukin 5. J Exp Med 1990;172:14251431.

17 Tominaga A, Takaki S, Koyama N, Katoh S, Matsumoto R, Migita M, Hitoshi Y, Hosoya Y, Yamauchi S, Kanai Y, Miyazaki J, Usuku G, Yamamura K, Takatsu K: Transgenic mice expressing a $\mathrm{B}$ cell growth and differentiation factor gene (interleukin 5) develop eosinophilia and autoantibody production. J Exp Med 1991;173:429-438.

18 Lee JJ, McGarry MP, Farmer SC, Denzler KL, Larson KA, Carrigan PE, Brenneise IE, Horton MA, Haczku A, Gelfand EW, Leikauf GD, Lee NA: Interleukin-5 expression in the lung epithelium of transgenic mice leads to pulmonary changes pathognomonic of asthma. J Exp Med 1997;185:2143-2156.

19 Nakajima H, Iwamoto I, Tomoe S, Matsumura $\mathrm{R}$, Tomioka $\mathrm{H}$, Takatsu $\mathrm{K}$, Yoshida S: CD4+ T-lymphocytes and interleukin-5 mediate antigen-induced eosinophil infiltration into the mouse trachea. Am Rev Respir Dis 1992;146:374-377.

20 Van Oosterhout AJ, Ladenius AR, Savelkoul HF, Van Ark I, Delsman KC, Nijkamp FP: Effect of anti-IL-5 and IL-5 on airway hyperreactivity and eosinophils in guinea pigs. Am Rev Respir Dis 1993;147:548-552.

21 Akutsu I, Kojima T, Kariyone A, Fukuda T, Makino S, Takatsu K: Antibody against interleukin-5 prevents antigen-induced eosinophil infiltration and bronchial hyperreactivity in the guinea pig airways. Immunol Lett 1995;45:109-116.

22 Foster PS, Hogan SP, Ramsay AJ, Matthaei KI, Young IG: Interleukin 5 deficiency abolishes eosinophilia, airways hyperreactivity, and lung damage in a mouse asthma model. J Exp Med 1996;183:195-201.

23 Kopf M, Brombacher F, Hodgkin PD, Ramsay AJ, Milbourne EA, Dai WJ, Ovington KS, Behm CA, Kohler G, Young IG, Matthaei KI: IL-5-deficient mice have a developmental defect in CD5+ B-1 cells and lack eosinophilia but have normal antibody and cytotoxic $\mathrm{T}$ cell responses. Immunity 1996;4:15-24.

24 Yoshida T, Ikuta K, Sugaya H, Maki K, Takagi M, Kanazawa H, Sunaga S, Kinashi T, Yoshimura K, Miyazaki J, Takaki S, Takatsu K: Defective B-1 cell development and impaired immunity against Angiostrongylus cantonensis in IL-5R $\alpha$-deficient mice. Immunity 1996;4:483-494.
25 Tanaka H, Kawada N, Yamada T, Kawada K, Takatsu K, Nagai H: Allergen-induced airway inflammation and bronchial responsiveness in interleukin-5 receptor $\alpha$ chaindeficient mice. Clin Exp Allergy 2000;30: 874-881.

26 Leckie MJ, ten Brincke A, Khan J, Diamant Z, O'Connor BJ, Walls CM, Mathur M, Cowley H, Chung KF, Djukanovic RJ, Hansel TT, Holgate ST, Sterk PJ, Barnes PJ: Effects of an interleukin-5 blocking monoclonal antibody on eosinophils, airway hyperresponsiveness and the late asthmatic response. Lancet 2000;356:2144-2148.

27 Tanaka H, Komai M, Nagao K, Ishizaki M, Kajiwara D, Takatsu K, Delespesse G, Nagai $\mathrm{H}$ : Role of interleukin-5 and eosinophils in allergen-induced airway remodeling in mice. Am J Respir Cell Mol Biol 2004;31:62-68.

28 Flood-Page P, Menzies-Gow A, Phipps S, Ying S, Wangoo A, Ludwig MS, Barnes N, Robinson D, Kay AB: Anti-IL-5 treatment reduces deposition of ECM proteins in the bronchial subepithelial basement membrane of mild atopic asthmatics. J Clin Invest 2003; 112:1029-1036.

29 Kay AB, Phipps S, Robinson DS: A role for eosinophils in airway remodelling in asthma. Trends Immunol 2004;25:477-482.

30 Wills-Karp M: Immunologic basis of antigen-induced airway hyperresponsiveness. Annu Rev Immunol 1999;17:255-281.

-31 Wills-Karp M: Interleukin-13 in asthma pathogenesis. Immunol Rev 2004;202:175190.

$>32$ Wynn TA: IL-13 effector functions. Annu Rev Immunol 2003;21:425-456.

$>33$ Grunig G, Warnock M, Wakil AE, Venkayya R, Brombacher F, Rennick DM, Sheppard D, Mohrs M, Donaldson DD, Locksley RM, Corry DB: Requirement for IL-13 independently of IL-4 in experimental asthma. Science 1998;282:2261-2263.

>34 Wills-Karp M, Luyimbazi J, Xu X, Schofield B, Neben TY, Karp CL, Donaldson DD: Interleukin-13: central mediator of allergic asthma. Science 1998;282:2258-2261.

>35 Walter DM, McIntire JJ, Berry G, McKenzie AN, Donaldson DD, DeKruyff RH, Umetsu DT: Critical role for IL-13 in the development of allergen-induced airway hyperreactivity. J Immunol 2001;167:4668-4675.

-36 Zhu Z, Homer RJ, Wang Z, Chen Q, Geba GP, Wang J, Zhang Y, Elias JA: Pulmonary expression of interleukin-13 causes inflammation, mucus hypersecretion, subepithelial fibrosis, physiologic abnormalities, and eotaxin production. J Clin Invest 1999;103: 779-788. 
-37 Shirakawa I, Deichmann KA, Izuhara I, Mao I, Adra CN, Hopkin JM: Atopy and asthma: genetic variants of IL-4 and IL-13 signalling. Immunol Today 2000;21:60-64.

$\checkmark 38$ Hauber HP, Bergeron C, Hamid Q: IL-9 in allergic inflammation. Int Arch Allergy Immunol 2004;134:79-87.

-39 Nicolaides NC, Holroyd KJ, Ewart SL, Eleff SM, Kiser MB, Dragwa CR, Sullivan CD, Grasso L, Zhang LY, Messler CJ, Zhou T, Kleeberger SR, Buetow KH, Levitt RC: Interleukin 9: a candidate gene for asthma. Proc Natl Acad Sci USA 1997;94:13175-13180.

-40 Shimbara A, Christodoulopoulos P, SoussiGounni A, Olivenstein R, Nakamura Y, Levitt RC, Nicolaides NC, Holroyd KJ, Tsicopoulos A, Lafitte JJ, Wallaert B, Hamid QA: IL-9 and its receptor in allergic and nonallergic lung disease: increased expression in asthma. J Allergy Clin Immunol 2000;105: 108-115.

-41 Temann UA, Geba GP, Rankin JA, Flavell RA: Expression of interleukin 9 in the lungs of transgenic mice causes airway inflammation, mast cell hyperplasia, and bronchial hyperresponsiveness. J Exp Med 1998;188: 1307-1320.

-42 Cheng G, Arima M, Honda K, Hirata H, Eda F, Yoshida N, Fukushima F, Ishii Y, Fukuda T: Anti-interleukin-9 antibody treatment inhibits airway inflammation and hyperreactivity in mouse asthma model. Am J Respir Crit Care Med 2002;166:409-416.

43 Townsend MJ, Fallon PG, Matthews DJ, Smith P, Jolin HE, McKenzie AN: IL-9 deficient mice establish fundamental roles for IL-9 in pulmonary mastocytosis and goblet cell hyperplasia but not T cell development. Immunity 2000;13:573-583.

-44 Iwamoto I, Nakajima H, Endo H, Yoshida S: Interferon $\gamma$ regulates antigen-induced eosinophil recruitment into the mouse airways by inhibiting the infiltration of CD $4+$ T cells. J Exp Med 1993;177:573-576.

-45 Li XM, Chopra RK, Chou TY, Schofield BH, Wills-Karp M, Huang SK: Mucosal IFN- $\gamma$ gene transfer inhibits pulmonary allergic responses in mice. J Immunol 1996;157:32163219.

46 Coyle AJ, Tsuyuki S, Bertrand C, Huang S, Aguet M, Alkan SS, Anderson GP: Mice lacking the IFN- $\gamma$ receptor have impaired ability to resolve a lung eosinophilic inflammatory response associated with a prolonged capacity of T cells to exhibit a Th2 cytokine profile. J Immunol 1996;156:2680-2685.

-47 Randolph DA, Carruthers CJ, Szabo SJ, Murphy KM, Chaplin DD: Modulation of airway inflammation by passive transfer of allergen-specific Th1 and Th2 cells in a mouse model of asthma. J Immunol 1999;162:23752383.

-48 Hansen G, Berry G, DeKruyff RH, Umetsu DT: Allergen-specific Th1 cells fail to counterbalance Th2 cell-induced airway hyperreactivity but cause severe airway inflammation. J Clin Invest 1999;103:175-183.
49 Randolph DA, Stephens R, Carruthers CJ, Chaplin DD: Cooperation between Th1 and Th2 cells in a murine model of eosinophilic airway inflammation. J Clin Invest 1999; 104:1021-1029.

50 Rissoan MC, Soumelis V, Kadowaki N, Grouard G, Briere F, de Waal Malefyt R, Liu YJ: Reciprocal control of T helper cell and dendritic cell differentiation. Science 1999; 283:1183-1186.

51 Naseer T, Minshall EM, Leung DY, Laberge S, Ernst P, Martin RJ, Hamid Q: Expression of IL-12 and IL-13 mRNA in asthma and their modulation in response to steroid therapy. Am J Respir Crit Care Med 1997;155: 845-851.

52 Kips JC, Brusselle GJ, Joos GF, Peleman RA, Tavernier JH, Devos RR, Pauwels RA: Interleukin-12 inhibits antigen-induced airway hyperresponsiveness in mice. Am J Respir Crit Care Med 1996;153:535-539.

53 Gavett SH, O’Hearn DJ, Li X, Huang SK, Finkelman FD, Wills-Karp M: Interleukin 12 inhibits antigen-induced airway hyperresponsiveness, inflammation, and Th2 cytokine expression in mice. J Exp Med 1995;182: 1527-1536.

54 Szabo SJ, Jacobson NG, Dighe AS, Gubler U, Murphy KM: Developmental commitment to the Th2 lineage by extinction of IL-12 signaling. Immunity 1995;2:665-675.

55 Okamura H, Tsutsui H, Komatsu T, Yutsudo M, Hakura A, Tanimoto T, Torigoe K, Okura T, Nukada Y, Hattori K, Akita K, Namba M, Tanabe F, Konishi K, Fukuda S, Kurimoto M: Cloning of a new cytokine that induces IFN$\gamma$ production by T cells. Nature $1995 ; 378$ : 88-91.

56 Kodama T, Matsuyama T, Kuribayashi K, Nishioka Y, Sugita M, Akira S, Nakanishi K, Okamura H: IL-18 deficiency selectively enhances allergen-induced eosinophilia in mice. J Allergy Clin Immunol 2000;105:4553.

57 Hofstra CL, Van Ark I, Hofman G, Kool M, Nijkamp FP, Van Oosterhout AJ: Prevention of Th2-like cell responses by coadministration of IL-12 and IL-18 is associated with inhibition of antigen-induced airway hyperresponsiveness, eosinophilia, and serum $\operatorname{IgE}$ levels. J Immunol 1998;161:5054-5060.

58 Sugimoto T, Ishikawa Y, Yoshimoto T, Hayashi N, Fujimoto J, Nakanishi K: IL-18 acts on memory Th1 cells to induce airway inflammation and hyperresponsiveness in a naive host mouse. J Exp Med 2004;199:535545.

59 Kumano K, Nakao A, Nakajima H, Hayashi F, Kurimoto M, Okamura H, Saito Y, Iwamoto I: Interleukin-18 enhances antigen-induced eosinophil recruitment into the mouse airways. Am J Respir Crit Care Med 1999; 160:873-878.
60 Tsutsui H, Yoshimoto T, Hayashi N, Mizutani $\mathrm{H}$, Nakanishi K: Induction of allergic inflammation by interleukin-18 in experimental animal models. Immunol Rev 2004; 202:115-138.

61 Hunter CA: New IL-12-family members: IL23 and IL-27, cytokines with divergent functions. Nat Rev Immunol 2005;5:521-531.

62 Takeda A, Hamano S, Yamanaka A, Hanada T, Ishibashi T, Mak TW, Yoshimura A, Yoshida H: Cutting edge: role of IL-27/WSX-1 signaling for induction of T-bet through activation of STAT1 during initial Th1 commitment. J Immunol 2003;170:4886-4890.

63 Artis D, Villarino A, Silverman M, He W, Thornton EM, Mu S, Summer S, Covey TM, Huang E, Yoshida H, Koretzky G, Goldschmidt M, Wu GD, de Sauvage F, Miller HR, Saris CJ, Scott P, Hunter CA: The IL-27 receptor (WSX-1) is an inhibitor of innate and adaptive elements of type 2 immunity. J Immunol 2004;173:5626-5634.

64 Miyazaki Y, Inoue H, Matsumura M, Matsumoto K, Nakano T, Tsuda M, Hamano S, Yoshimura A, Yoshida H: Exacerbation of experimental allergic asthma by augmented Th2 responses in WSX-1-deficient mice. J Immunol 2005;175:2401-2407.

65 Moseley TA, Haudenschild DR, Rose L, Reddi AH: Interleukin-17 family and IL-17 receptors. Cytokine Growth Factor Rev 2003; 14:155-174.

66 Weaver CT, Harrington LE, Mangan PR, Gavrieli M, Murphy KM: Th17: an effector CD4 T cell lineage with regulatory $\mathrm{T}$ cell ties. Immunity 2006;24:677-688.

67 Kawaguchi M, Adachi M, Oda N, Kokubu F, Huang SK: IL-17 cytokine family. J Allergy Clin Immunol 2004;114:1265-1273.

68 Linden A: Role of interleukin-17 and the neutrophil in asthma. Int Arch Allergy Immunol 2001;126:179-184.

69 Jatakanon A, Uasuf C, Maziak W, Lim S, Chung KF, Barnes PJ: Neutrophilic inflammation in severe persistent asthma. Am J Respir Crit Care Med 1999;160:1532-1539.

70 Fort MM, Cheung J, Yen D, Li J, Zurawski SM, Lo S, Menon S, Clifford T, Hunte B, Lesley R, Muchamuel T, Hurst SD, Zurawski G, Leach MW, Gorman DM, Rennick DM: IL25 induces IL-4, IL-5, and IL-13 and Th2-associated pathologies in vivo. Immunity 2001; 15:985-995.

71 Ikeda K, Nakajima H, Suzuki K, Kagami S, Hirose K, Suto A, Saito Y, Iwamoto I: Mast cells produce interleukin-25 upon FceRImediated activation. Blood 2003;101:35943596.

72 Hurst SD, Muchamuel T, Gorman DM, Gilbert JM, Clifford T, Kwan S, Menon S, Seymour B, Jackson C, Kung TT, Brieland JK, Zurawski SM, Chapman RW, Zurawski G, Coffman RL: New IL-17 family members promote Th1 or Th2 responses in the lung: in vivo function of the novel cytokine IL-25. J Immunol 2002;169:443-453. 
73 Pan G, French D, Mao W, Maruoka M, Risser P, Lee J, Foster J, Aggarwal S, Nicholes K, Guillet S, Schow P, Gurney AL: Forced expression of murine IL-17E induces growth retardation, jaundice, a Th2-biased response, and multiorgan inflammation in mice. J Immunol 2001;167:6559-6567.

-74 Tamachi T, Maezawa Y, Ikeda K, Kagami SI, Hatano M, Seto Y, Suto A, Suzuki K, Watanabe N, Saito Y, Tokuhisa T, Iwamoto I, Nakajima H: IL-25 enhances allergic airway inflammation by amplifying a Th2 celldependent pathway in mice. J Allergy Clin Immunol 2006;118:606-614.

75 Letuve S, Lajoie-Kadoch S, Audusseau S, Rothenberg ME, Fiset PO, Ludwig MS, Hamid Q: IL-17E upregulates the expression of proinflammatory cytokines in lung fibroblasts. J Allergy Clin Immunol 2006;117: 590-596.

76 Babu KS, Davies DE, Holgate ST: Role of tumor necrosis factor $\alpha$ in asthma. Immunol Allergy Clin North Am 2004;24:583-597.

-77 Keatings VM, Collins PD, Scott DM, Barnes PJ: Differences in interleukin- 8 and tumor necrosis factor- $\alpha$ in induced sputum from patients with chronic obstructive pulmonary disease or asthma. Am J Respir Crit Care Med 1996;153:530-534.

-78 Thomas PS, Yates DH, Barnes PJ: Tumor necrosis factor- $\alpha$ increases airway responsiveness and sputum neutrophilia in normal human subjects. Am J Respir Crit Care Med 1995; 152:76-80.

79 Kips JC, Tavernier J, Pauwels RA: Tumor necrosis factor causes bronchial hyperresponsiveness in rats. Am Rev Respir Dis 1992;145: 332-336.

-80 Berry MA, Hargadon B, Shelley M, Parker D, Shaw DE, Green RH, Bradding P, Brightling CE, Wardlaw AJ, Pavord ID: Evidence of a role of tumor necrosis factor $\alpha$ in refractory asthma. N Engl J Med 2006;354:697-708.

-81 Liu YJ: Thymic stromal lymphopoietin: master switch for allergic inflammation. J Exp Med 2006;203:269-273.

-82 Pandey A, Ozaki K, Baumann H, Levin SD, Puel A, Farr AG, Ziegler SF, Leonard WJ, Lodish HF: Cloning of a receptor subunit required for signaling by thymic stromal lymphopoietin. Nat Immunol 2000;1:59-64.

83 Park LS, Martin U, Garka K, Gliniak B, Di Santo JP, Muller W, Largaespada DA, Copeland NG, Jenkins NA, Farr AG, Ziegler SF, Morrissey PJ, Paxton R, Sims JE: Cloning of the murine thymic stromal lymphopoietin (TSLP) receptor: formation of a functional heteromeric complex requires interleukin 7 receptor. J Exp Med 2000;192:659-670.
84 Ito T, Wang YH, Duramad O, Hori T, Delespesse GJ, Watanabe N, Qin FX, Yao Z, Cao W, Liu YJ: TSLP-activated dendritic cells induce an inflammatory $\mathrm{T}$ helper type 2 cell response through OX40 ligand. J Exp Med 2005;202:1213-1223.

85 Wang YH, Ito T, Wang YH, Homey B, Watanabe N, Martin R, Barnes CJ, McIntyre BW, Gilliet M, Kumar R, Yao Z, Liu YJ: Maintenance and polarization of human $\mathrm{TH} 2$ central memory $\mathrm{T}$ cells by thymic stroma lymphopoietin-activated dendritic cells. Immunity 2006;24:827-838.

86 Zhou B, Comeau MR, De Smedt T, Liggitt HD, Dahl ME, Lewis DB, Gyarmati D, Aye T, Campbell DJ, Ziegler SF: Thymic stromal lymphopoietin as a key initiator of allergic airway inflammation in mice. Nat Immunol 2005;6:1047-1053.

87 Al-Shami A, Spolski R, Kelly J, Keane-Myers A, Leonard WJ: A role for TSLP in the development of inflammation in an asthma model. J Exp Med 2005;202:829-839.

88 Ying S, O’Connor B, Ratoff J, Meng Q, Mallett $\mathrm{K}$, Cousins D, Robinson D, Zhang G, Zhao J, Lee TH, Corrigan C: Thymic stromal lymphopoietin expression is increased in asthmatic airways and correlates with expression of Th2-attracting chemokines and disease severity. J Immunol 2005;174:81838190.

89 Leonard WJ, Spolski R: Interleukin-21: a modulator of lymphoid proliferation, apoptosis and differentiation. Nat Rev Immunol 2005;5:688-698.

90 Kasaian MT, Whitters MJ, Carter LL, Lowe LD, Jussif JM, Deng B, Johnson KA, Witek JS, Senices M, Konz RF, Wurster AL, Donaldson DD, Collins M, Young DA, Grusby MJ: IL-21 limits NK cell responses and promotes antigen-specific $\mathrm{T}$ cell activation: a mediator of the transition from innate to adaptive immunity. Immunity 2002;16:559-569.

91 Ozaki K, Spolski R, Feng CG, Qi CF, Cheng J, Sher A, Morse HC 3rd, Liu C, Schwartzberg PL, Leonard WJ: A critical role for IL-21 in regulating immunoglobulin production. Science 2002;298:1630-1634.

92 Suto A, Nakajima H, Hirose K, Suzuki K, Kagami S, Seto Y, Hoshimoto A, Saito Y, Foster DC, Iwamoto I: Interleukin 21 prevents antigen-induced IgE production by inhibiting germ line $\mathrm{C} \varepsilon$ transcription of IL-4-stimulated B cells. Blood 2002;100:4565-4573.

93 Suto A, Wurster AL, Reiner SL, Grusby MJ: IL-21 inhibits IFN- $\gamma$ production in developing Th1 cells through the repression of Eomesodermin expression. J Immunol 2006; 177:3721-3727.
94 Dillon SR, Sprecher C, Hammond A, Bilsborough J, Rosenfeld-Franklin M, Presnell SR, Haugen HS, Maurer M, Harder B, Johnston J, Bort S, Mudri S, Kuijper JL, Bukowski T, Shea P, Dong DL, Dasovich M, Grant FJ, Lockwood L, Levin SD, LeCiel C, Waggie K, Day H, Topouzis S, Kramer J, Kuestner R, Chen Z, Foster D, Parrish-Novak J, Gross JA: Interleukin 31, a cytokine produced by activated $T$ cells, induces dermatitis in mice. Nat Immunol 2004;5:752760.

95 Sonkoly E, Muller A, Lauerma AI, Pivarcsi A, Soto H, Kemeny L, Alenius H, Dieu-Nosjean MC, Meller S, Rieker J, Steinhoff M, Hoffmann TK, Ruzicka T, Zlotnik A, Homey B: IL-31: a new link between T cells and pruritus in atopic skin inflammation. J Allergy Clin Immunol 2006;117:411-417.

-96 Bilsborough J, Leung DY, Maurer M, Howell M, Boguniewicz M, Yao L, Storey $\mathrm{H}$, LeCiel C, Harder B, Gross JA: IL-31 is associated with cutaneous lymphocyte antigen-positive skin homing $\mathrm{T}$ cells in patients with atopic dermatitis. J Allergy Clin Immunol 2006;117:418-425.

\$97 Trajkovic V, Sweet MJ, Xu D: T1/ST2-an IL1 receptor-like modulator of immune responses. Cytokine Growth Factor Rev 2004;15:87-95.

$\checkmark 98$ Lohning M, Stroehmann A, Coyle AJ, Grogan JL, Lin S, Gutierrez-Ramos JC, Levinson D, Radbruch A, Kamradt T: T1/ST2 is preferentially expressed on murine Th2 cells, independent of interleukin 4 , interleukin 5, and interleukin 10, and important for Th2 effector function. Proc Natl Acad Sci USA 1998;95:6930-6935.

$\checkmark 99$ Coyle AJ, Lloyd C, Tian J, Nguyen T, Erikkson C, Wang L, Ottoson P, Persson P, Delaney T, Lehar S, Lin S, Poisson L, Meisel C, Kamradt T, Bjerke T, Levinson D, Gutierrez-Ramos JC: Crucial role of the interleukin 1 receptor family member T1/ST2 in T helper cell type 2-mediated lung mucosal immune responses. J Exp Med 1999;190: 895-902.

100 Townsend MJ, Fallon PG, Matthews DJ, Jolin HE, McKenzie AN: T1/ST2-deficient mice demonstrate the importance of $\mathrm{T} 1 /$ ST2 in developing primary $\mathrm{T}$ helper cell type 2 responses. J Exp Med 2000;191: 1069-1076.

-101 Schmitz J, Owyang A, Oldham E, Song Y, Murphy E, McClanahan TK, Zurawski G, Moshrefi M, Qin J, Li X, Gorman DM, Bazan JF, Kastelein RA: IL-33, an interleukin1-like cytokine that signals via the IL-1 receptor-related protein ST2 and induces T helper type 2-associated cytokines. Immunity $2005 ; 23: 479-490$. 